\title{
EFFECTS OF CALCIUM AND UV-C TREATMENTS ON PHYSICAL AND BIOCHEMICAL QUALITY ATTRIBUTES OF PEPPER THROUGHOUT COLD STORAGE
}

\author{
ÇAVUŞOĞLU, Ş. \\ Department of Horticulture, Faculty of Agriculture, Van Yuzuncu Yil University, Van, Turkey \\ (e-mail: seydacavusoglu@yyu.edu.tr; phone: +90-444-5065-21685) \\ (Received $8^{\text {th }}$ Aug 2018; accepted $5^{\text {th }}$ Oct 2018)
}

\begin{abstract}
Effects of pre-harvest calcium chloride and post-harvest UV-C (200-280 nm ultraviolet light) treatments on pepper fruits (Capsicum annuиm L. cv. Mertcan F1) were investigated in this study. Calcium treatments usually delay softening in horticultural crops. UV$\mathrm{C}$ treatments prevent decay on fruit surface. However, instead of these physical attributes, changes in the chemical composition of fruit were investigated in this study. Experimental treatments were arranged as control (without any treatments), UV-C, Ca and Ca + UV-C. Treated fruits were stored in a cold storage at $0{ }^{\circ} \mathrm{C}$ and $95 \%$ relative humidity for 10 days. Samples were taken in every 2 days of the storage and $\mathrm{pH}$, titratable acidity (TA), soluble solids content (SSC), color change, total phenolic content (TPC) and total antioxidant capacity (TAC) were determined. All experimental treatments all increased SSC, titratable acidity, total phenolic content and total antioxidant capacity. Particularly, treatments containing $\mathrm{Ca}$ yielded the greatest increases in SSC and titratable acidity. UV-C $+\mathrm{Ca}$ treatment preserved the color intensity (chroma - C) the best (32.85). Total phenolic content and total antioxidant capacity had the least change with UV-C treatment. UV-C + Ca was recommended as the best treatment keeping quality attributes of 'cv. Mertcan F1' pepper throughout the cold storage for 10 days. Such 10-day extension is a significant criterion for pepper storage and marketing.
\end{abstract}

Keywords: Capsicum annuum L., antioxidant, total phenolic content, postharvest

\section{Introduction}

Turkey has ecologically quite available conditions for pepper farming. It is possible to grow peppers all year-long in Turkey. Annual productions, yield levels and quality attributes are all greater than world averages (Vural and et al., 2000; Gunay, 2005). Turkey produces 2,127,944 tons of pepper annually and such an amount constitutes about $7 \%$ of world production (32,324,345 tons). Following China and Mexico, Turkey has the third place in world pepper production (FAOSTAT, 2014). Despite high production volumes, deficiency in storage and packaging techniques causes significant losses in fresh peppers. As it is a quickly rotting product, storage and delivery to markets are vital issues for peppers (Erdogmus et al., 2015).

Pepper (Capsicum annuum L.) is originated from tropical and sub-tropical countries of America and it is an essential vegetable for healthy life. Fruits are quite rich in biological agents such as vitamins, antioxidants and other phytochemicals. Fruits are consumed in various ways; as fresh vegetable in salads, fried, cooked with meat or olive oil, as pepper paste, pickle and spice (Vural et al., 2000; Frank et al., 2005; Crosby, 2008). Peppers are also rich in antioxidants, ascorbic acid, carotenoid and vitamin $\mathrm{E}$, thus used in prevention of some cancer cases, heart diseases and cardiovascular diseases (Simonne et al., 1997; Salk et al., 2008). 
Peppers have non-climacteric fruits (Watkins, 2002) and thus they are not significantly influenced by post-harvest ethylene synthesis. Besides, fresh pepper fruits have quite high water contents shortening their shelf life and speeding up deteriorations. Especially when the pepper fruits were kept in room conditions, the physiological deterioration is most likely to be caused by water loss, congestion and wrinkles. Consumers prefer peppers with a firm and fresh appearance. Therefore, in order to maintain the quality of peppers, like other products, they must be kept in cold storages with high relative humidity and low temperatures. Fresh pepper fruits can be stored between 7 to $10 \mathrm{C}^{\circ}$ and $90-95 \%$ relative humidity for 1-3 weeks (Hardenburg et al., 1986; Snowdon, 1992). This time period can be extended up to 35-45 days by modified atmosphere packages (Rodov et al., 1995; Halloran et al., 2000; Demirdoven et al., 2006). Cold damage is the most important factor restricting the preservation of peppers in cold storages. Low temperatures below $7-10 \mathrm{C}^{\circ}$ cause softening, shrinkage, drying and pathological disorders in peppers, which severely reduce the quality and acceptability of the product (Mercier et al., 2001; Nyanjage et al., 2005).

Calcium facilitates calcium pectate formation on cell walls, thus increases fruit firmness. Such a case then facilitates the preservation of the product for a long period. Besides, as in many vegetables, calcium also prevents blossom-end rotting in peppers. Pre and post-harvest calcium treatments delay aging during the storage and marketing stages and these treatments do not have any negative effects on appearance (Lester and Grusak, 2000; Hernandez-Munoz, 2006; Chen et al., 2011). Ca treatments generally reduce respiration and metabolic activity in fruits. As a result, the breakdown of carbohydrates were delayed and increasing of soluble solids content (SSC) in peppers were decreased (Rao et al., 2011).

Erdogmus et al. (2015) reported that post-harvest application of $2 \% \mathrm{CaCl}_{2}$ to the ' $\mathrm{cv}$. Yalova Yağlık 28' pepper at $0 \mathrm{C}^{\circ}$ and $90 \%$ relative humidity resulted in $11.6 \%$ weight loss after 30 days of storage and a decrease was the lowest as compared to the other applications. Rao et al. (2011) immersed fresh sweet 'Indra' peppers into $0.5,1.0$ and $1.5 \%$ calcium chloride solutions for $15 \mathrm{~min}$ and stored peppers at $10{ }^{\circ} \mathrm{C}$ and $25^{\circ} \mathrm{C}$ for 18 days in polyethylene packages. Researchers reported that significant effects of $1.5 \%$ calcium chloride treatment on SSC, titratable acidity (TA) and $\mathrm{pH}(\mathrm{p}<0.05)$ and weight loss both during the storage and the shelf life. It was concluded that fruits could be stored for up to 71 days without significant losses in taste.

Ultraviolet-C (UV-C) is a technology commonly used in surface and water disinfection as well as in fruit juice pasteurization (Koutchma et al., 2016). Recent studies showed that UV-C light stimulated the formation of secondary metabolites when it was applied as an abiotic stressor to the plants (Alothman et al., 2009). UV-light treatments increased antioxidants and total phenolics of red peppers during the storage (Andrade-Cuvi, 2011; Perez-Ambrocio et al., 2018). Vicente et al. (2005) applied UV-C light to 'Zafiro' pepper with red color and stored peppers in a cold storage at $10 \mathrm{C}^{\circ}$ and $90 \%$ relative humidity for 18 days. The $7 \mathrm{kJm}^{-2} \mathrm{UV}-\mathrm{C}$ treatments better preserved color parameters, carotenoid levels and fruit firmness and reduced decay rates, but did not affect the changes in SSC values. UV-C treatments had lower total phenolic content. Abbasi et al. (2015) applied UV-C ( 3 and $5 \mathrm{~min}$ at $254 \mathrm{~nm}$ ), the edible coatings aleo gel, ginger oil and chitosan to 'Royal Wonder' bell pepper at different rates and stored treated fruits 
at $8-9 \mathrm{C}^{\circ}$ and $80-85 \%$ relative humidity for 24 days. Researchers reported that 5 min UV-C treatments better preserved fruit firmness, SSC, color parameters, ascorbic acid contents and titratable acidity. UV-C (short-wave ultraviolet radiation) is a chemical-free method and it provides longer-lasting, high-quality preservation of products by preventing or eliminating the development of pathogens.

This study investigated the effects of alternative environment-friendly methods (calcium and UV-C treatments) on preservation of quality attributes of fresh peppers throughout the cold storage. Shelf life of fresh peppers is quite short due to softening, water loss and decay. Extension of the shelf life for a few days is very important for the marketing of the product. Number of studies on calcium and UV-C treatments in peppers is quite limited. Thus, the primary objective of the present study was set as to extend shelf life of fresh peppers with calcium and UV-C treatments.

\section{Materials and methods}

\section{Fruit material}

The 'cv. Mertcan F1'(Capsicum annum L.) peppers used in this study were obtained from a producer farm in the Kazanl1 distict in Mersin province, Turkey ( $36^{\circ} 49^{\prime} 14.5956^{\prime \prime}$ and $34^{\circ} 45^{\prime} 22.0536$ "), toward the end of the production period spanning October 2016 to January 2017. This pepper is a sweet and early type. It is cultivated in greenhouses at $40 \mathrm{~cm} \times 50 \mathrm{~cm}$ spacing by fertilization and drip irrigation. Peppers were transported by air-conditioned vehicles to The Postharvest Laboratory of Van Yuzuncu Yil University, Faculty of Agriculture, Department of Horticulture. Initially, $\mathrm{pH}, \mathrm{SSC}$, titratable acidity, color parameters, total phenolic content and total antioxidant capacity were measured before placing the peppers into cold storage.

\section{Experimental plan}

The pepper fruits to be used in experiments were packed due to the fact that it is cheap and lightweight in styrofoam packs of $0.5 \mathrm{~kg}, 30$ fruits in each and 2 replications for each treatment, and then they were placed in cardboard boxes of 5 $\mathrm{kg}$. Experimental treatments were arranged as; a-) Control, b-) UV-C, c-) $\mathrm{Ca}$ and d-) $\mathrm{Ca}+\mathrm{UV}-\mathrm{C}$. For pre-harvest $\mathrm{Ca}$ treatments, $12.1 \%$ commercial calcium fertilizer (DRT speedfol calcium) was applied for 2 days and 1 hour per week at $500 \mathrm{cc} / \mathrm{da}$ rate of application.

UV-C was applied as specified by Vicente et al. (2005); 30 fruits were placed on a sterile plastic tray $30 \mathrm{~cm}$ below 4 sterile UV-C lamps (TUV G30T8, $30 \mathrm{~W}$, Philips, Argentina) with $254 \mathrm{~nm}$ light emission and applied at $14 \mathrm{kJm}^{-2}$. In order to get better light during the application, the peppers were manually rotated around the surface three times. The radiation intensity was measured by a digital UV radiometer (Cole-Parmer Instrument Company, Vernon Hills, Ill.).

Fruits were stored at $0{ }^{\circ} \mathrm{C}$ and $95 \%$ relative humidity for 10 days and they were analyzed in every 2 days.

The SSC ratio was measured with a digital refractometer (Atago, Tokyo, Japan) and the results were expressed in Brix. Titratable acidity was measured as the 
quantity of $0.1 \mathrm{~N} \mathrm{NaOH}$ solution consumed in titration until a $\mathrm{pH}$ values of 8.2 and the results were expressed as citric acid percentage. Fruit color changes were measured with a Minolta colormeter (Model CR-400; Osoka, Japan). L shows brightness ( 0 black, 100 white), 'a' shows green color change (60 green, +60 red), b bluish change ( -60 blue, +60 yellow), $\mathrm{C}$ color intensity (low values indicate dark color) and h (hue) angle value (0 red-violet, 90 yellow, 180 blue-green, 270 blue).

In order to find the total phenolic content; $5 \mathrm{~g}$ fresh pepper tissue was extracted with $25 \mathrm{ml}$ of $80 \%$ methanol and homogenized at medium speed in a homogenizer (Ika Ultra-Turrax T25 Basic, Germany) for $2 \mathrm{~min}$. Then the mixture was kept in dark for 14-16 hours at $4{ }^{\circ} \mathrm{C}$. Samples were filtered through filter papers and tubed. Samples were stored at $-20{ }^{\circ} \mathrm{C}$ until the analyses. Total phenolic content was determined by a spectrophotometer (Varian Bio 100, Australia) in accordance with Swain and Hillis' method (1959), in which the Folin-Ciocaltaeu calorimetric method was modified. The absorbance of the samples in the spectrophotometer at wavelength of $725 \mathrm{~nm}$ was identified, and total phenolic content was expressed as Gallic acid equivalent (GAE) $\mathrm{mg} / 100 \mathrm{~g}$ fresh weight (FW).

Antioxidant capacity specified by Benzie and Starin (1996), Ferric Reducing Antioxidant Power (FRAP), was used to determine the total antioxidant capacity. The absorbance of the samples in the spectrophotometer at a wavelength of 593 $\mathrm{nm}$ was identified and the total antioxidant capacity was expressed as $\mu$ mol trolox equivalent (TE) / g FW.

Experimental data were subjected to variance analysis with SPSS 11.5 software in accordance with randomized sampling design. Means were compared with Duncan's multiple range test at $p<0.05$. LSD (Least Significant Differences) test was used to analyze the differences between treatments and intervals.

\section{Results and discussion}

The titratable acidity values of the 'cv. Mertcan F1' pepper fruits increased slightly with $\mathrm{Ca}$ and post-harvest UV-C treatments during the 10-day storage period (Table 1). The effects of all treatments on TA were found to be insignificant $(p>0.05)$. It can also be stated that increase in TA and SSC was resulted from loss of water in fresh peppers in time. Despite the slight increases in TA, as stated by Rao et al. (2011), use of fruit organic acid in respiration slowed down the conversion of carbon dioxide and water. Parallel to present findings, Erdogmus et al. (2015) reported insignificant changes in $1 \%$ and $2 \% \mathrm{CaCl}_{2}-$ treated 'Yalova Yaglik 28' pepper fruits throughout the storage for 15 and 30 days at $7.5{ }^{\circ} \mathrm{C}$ with $90 \%$ relative humidity $(\mathrm{RH})$. Likewise, Rao et al. (2011) found that $1.5 \% \mathrm{CaCl}_{2}$ treatments preserved TA of 'Indra' fresh sweet peppers during storage during 18 days at $10{ }^{\circ} \mathrm{C}$ and $25^{\circ} \mathrm{C}$ shelf life as compared to the control fruits. Such slight changes in TA ensure that pepper taste could be preserved for a long time.

The $\mathrm{pH}$ values of ' $\mathrm{cv}$. Mertcan F1' pepper fruits did not change much in the first 8 days of storage, while the values decreased in the last 2 days (Table 1). Similar to present study, Rao et al. (2011) applied calcium to peppers, Abbasi et al. (2015) applied UV-C to 'Royal Wonder' bell peppers and they both indicated insignificant effects of experimental treatments on $\mathrm{pH}$ values of the peppers 
throughout the storage. In present study, slight increase in titratable acidity at the end of storage was effective in reducing the $\mathrm{pH}$ values.

The effects of treatments and storage periods on SSC ratios were also found to be insignificant $(p>0.05)$. There was a slight increase in SSC ratios in all treatments as compared to the initial values (Table 1). The UV-C applications of Vicente et al. (2005) to 'Zafiro' pepper and Abbasi et al. (2015) to 'Royal Wonder' bell pepper and $\mathrm{CaCl}_{2}$ application of Rao et al. (2011) to 'Indra' sweet pepper preserved the SSC values as it was in present study. The SSC increase was high at the beginning due to water loss. With the progress of ripening throughout the storage, inherent sugar is used for respiration, thus increase in SSC slowed down toward to end of storage.

As compared to the initial values, color lightness ( $\left.\mathrm{L}^{*}\right)$ values decreased in control and $\mathrm{Ca}$ treatments and brightness values increased in UV-C and $\mathrm{Ca}+\mathrm{UV}$ $\mathrm{C}$ treatments during the first 2 days and then decreased until the $4^{\text {th }}$ day. At the end of the $10^{\text {th }}$ day, the effects of all treatments on brightness was not found to be significant $(p>0.05)$. The change in brightness values was irregular in all treatments and they all had different results (Table 1 and Fig. 1). Such changes in color parameters were attributed different maturity levels at harvest. Abbasi et al. (2015) reported that UV-C treatments did not have significant effects on $\mathrm{L}^{*}$ values of 'Royal Wonder' bell pepper. In present study, despite fluctuations during cold storage, there was no significant change in the initial value of $\mathrm{L}^{*}$ during the 10 days of storage. As indicated also by Abbasi et al. (2015), such insignificant effects of UV-C treatments were because of the chemical structure of the wax layer over the cuticle and its effects on the reflection of light.

Table 1. Effects of Ca and UV-C treatments on pH, titratable acidity (TA), soluble solids content (SSC), pH, total phenolic content (TPC), total antioxidant capacity (TAC) and color parameters $\left(L^{*}, a^{*}, b^{*}, C\right.$ and $\left.h^{\circ}\right)$ of pepper fruits stored at $0^{\circ} \mathrm{C}$ and $90-95 \%$ relative humidity for 10 days

\begin{tabular}{|c|c|c|c|c|c|}
\hline Parameter & $\begin{array}{c}\text { Storage } \\
\text { time }\end{array}$ & Control & Control+UV & $\mathbf{C a}$ & $\mathbf{C a}+\mathbf{U V}$ \\
\hline \multirow{6}{*}{$\mathrm{pH}$} & 0 & $6.610 \pm 0.010 \mathrm{~A} \mathrm{a}$ & $6.425 \pm 0.175 \mathrm{~A} \mathrm{a}$ & $6.220 \pm 0.180 \mathrm{Aab}$ & $6.360 \pm 0.210 \mathrm{~A} \mathrm{a}$ \\
\hline & 2 & $6.310 \pm 0.010 \mathrm{~A} \mathrm{~b}$ & $6.400 \pm 0.030 \mathrm{~A} \mathrm{a}$ & $6.460 \pm 0.010 \mathrm{~A} \mathrm{a}$ & $6.015 \pm 0.135 \mathrm{~B}$ a \\
\hline & 4 & $6.065 \pm 0.025 \mathrm{~A} \mathrm{~b}$ & $6.105 \pm 0.205 \mathrm{~A} \mathrm{a}$ & $6.055 \pm 0.045 \mathrm{~A} \mathrm{~b}$ & $6.405 \pm 0.265 \mathrm{~A} \mathrm{a}$ \\
\hline & 6 & $6.160 \pm 0.010 \mathrm{~A} \mathrm{~b}$ & $6.205 \pm 0.005 \mathrm{~A} \mathrm{a}$ & $6.305 \pm 0.025 \mathrm{Aab}$ & $6.220 \pm 0.110 \mathrm{~A} \mathrm{a}$ \\
\hline & 8 & $6.240 \pm 0.060 \mathrm{~B} \mathrm{~b}$ & $6.450 \pm 0.040 \mathrm{~A} \mathrm{a}$ & $6.485 \pm 0.035 \mathrm{~A} \mathrm{a}$ & $6.440 \pm 0.040 \mathrm{~A} \mathrm{a}$ \\
\hline & 10 & $5.795 \pm 0.155 \mathrm{~A} \mathrm{c}$ & $6.055 \pm 0.145 \mathrm{~A} \mathrm{a}$ & $6.055 \pm 0.165 \mathrm{~A} \mathrm{~b}$ & $5.900 \pm 0.070 \mathrm{~A} \mathrm{a}$ \\
\hline \multirow{6}{*}{ SSC } & 0 & $3.950 \pm 0.050 \mathrm{~A} \mathrm{a}$ & $3.850 \pm 0.150 \mathrm{~A} \mathrm{a}$ & $4.050 \pm 0.350 \mathrm{~A} \mathrm{a}$ & $4.400 \pm 0.200 \mathrm{~A} \mathrm{a}$ \\
\hline & 2 & $3.950 \pm 0.350 \mathrm{~A} \mathrm{a}$ & $4.100 \pm 0.500 \mathrm{~A} \mathrm{a}$ & $4.250 \pm 0.050 \mathrm{~A} \mathrm{a}$ & $4.450 \pm 0.050 \mathrm{~A} \mathrm{a}$ \\
\hline & 4 & $4.350 \pm 0.150 \mathrm{~A} \mathrm{a}$ & $4.050 \pm 0.350 \mathrm{~A} \mathrm{a}$ & $4.550 \pm 0.250 \mathrm{~A} \mathrm{a}$ & $4.650 \pm 0.250 \mathrm{~A} \mathrm{a}$ \\
\hline & 6 & $4.050 \pm 0.350 \mathrm{~A} \mathrm{a}$ & $4.350 \pm 0.150 \mathrm{~A} \mathrm{a}$ & $4.450 \pm 0.150 \mathrm{~A} \mathrm{a}$ & $4.700 \pm 0.300 \mathrm{~A} \mathrm{a}$ \\
\hline & 8 & $4.300 \pm 0.200 \mathrm{~A} \mathrm{a}$ & $4.450 \pm 0.150 \mathrm{~A} \mathrm{a}$ & $4.500 \pm 0.200 \mathrm{~A} \mathrm{a}$ & $4.700 \pm 0.200 \mathrm{~A} \mathrm{a}$ \\
\hline & 10 & $4.400 \pm 0.000 \mathrm{~A} \mathrm{a}$ & $4.300 \pm 0.000 \mathrm{~A} \mathrm{a}$ & $4.450 \pm 0.050 \mathrm{Aa}$ & $4.600 \pm 0.200 \mathrm{~A} \mathrm{a}$ \\
\hline \multirow{6}{*}{$\mathrm{TE}$} & 0 & $0.029 \pm 0.003 \mathrm{~A} \mathrm{c}$ & $0.032 \pm 0.000 \mathrm{~A} \mathrm{a}$ & $0.029 \pm 0.003 \mathrm{Acd}$ & $0.032 \pm 0.000 \mathrm{~A} \mathrm{c}$ \\
\hline & 2 & $0.029 \pm 0.003 \mathrm{~A} \mathrm{c}$ & $0.032 \pm 0.000 \mathrm{~A} \mathrm{a}$ & $0.032 \pm 0.000 \mathrm{Acd}$ & $0.029 \pm 0.003 \mathrm{~A} \mathrm{c}$ \\
\hline & 4 & $0.035 \pm 0.003 \mathrm{~A} \mathrm{bc}$ & $0.042 \pm 0.010 \mathrm{~A} \mathrm{a}$ & $0.026 \pm 0.000 \mathrm{~A} \mathrm{~d}$ & $0.042 \pm 0.003 \mathrm{~A} \mathrm{~b}$ \\
\hline & 6 & $0.035 \pm 0.003 \mathrm{~A} \mathrm{bc}$ & $0.035 \pm 0.003 \mathrm{~A} \mathrm{a}$ & $0.035 \pm 0.003 \mathrm{Abc}$ & $0.042 \pm 0.003 \mathrm{~A} \mathrm{~b}$ \\
\hline & 8 & $0.042 \pm 0.003 \mathrm{~A} \mathrm{~b}$ & $0.042 \pm 0.003 \mathrm{~A} \mathrm{a}$ & $0.042 \pm 0.003 \mathrm{Aab}$ & $0.045 \pm 0.000 \mathrm{~A} \mathrm{ab}$ \\
\hline & 10 & $0.048 \pm 0.003 \mathrm{~A} \mathrm{a}$ & $0.048 \pm 0.003 \mathrm{~A} \mathrm{a}$ & $0.048 \pm 0.003 \mathrm{~A} \mathrm{a}$ & $0.051 \pm 0.000 \mathrm{~A} \mathrm{a}$ \\
\hline
\end{tabular}




\begin{tabular}{|c|c|c|c|c|c|}
\hline \multirow{6}{*}{$\mathrm{L}^{*}$} & 0 & $40.255 \pm 1.725 \mathrm{~A} \mathrm{ab}$ & $40.215 \pm 0.415 \mathrm{~A} a b$ & $41.330 \pm 0.010 \mathrm{~A} \mathrm{a}$ & $40.075 \pm 0.645 \mathrm{~A} \mathrm{ab}$ \\
\hline & 2 & $39.730 \pm 0.470 \mathrm{~B} a b$ & $41.310 \pm 0.420 \mathrm{~A} \mathrm{a}$ & $40.15 \pm 0.32 \mathrm{ABab}$ & $40.640 \pm 0.320 \mathrm{AB}$ a \\
\hline & 4 & $38.685 \pm 0.435 \mathrm{~B} \mathrm{~b}$ & $39.685 \pm 0.165 \mathrm{~A} \mathrm{~b}$ & $38.170 \pm 0.090 \mathrm{Bb}$ & $38.310 \pm 0.020 \mathrm{~B} \mathrm{ab}$ \\
\hline & 6 & $42.050 \pm 0.010 \mathrm{~A} \mathrm{a}$ & $40.070 \pm 0.350 \mathrm{~B} \mathrm{ab}$ & $39.905 \pm 0.655 \mathrm{Bab}$ & $41.705 \pm 0.145 \mathrm{~A} \mathrm{a}$ \\
\hline & 8 & $41.185 \pm 0.165 \mathrm{~A} \mathrm{ab}$ & $40.870 \pm 0.290 \mathrm{ABab}$ & $41.620 \pm 0.370 \mathrm{~A} \mathrm{a}$ & $38.925 \pm 0.935 \mathrm{~B} \mathrm{ab}$ \\
\hline & 10 & $34.630 \pm 0.400 \mathrm{~A} \mathrm{c}$ & $35.520 \pm 0.550 \mathrm{~A} \mathrm{c}$ & $33.495 \pm 1.535 \mathrm{Ac}$ & $36.125 \pm 2.395 \mathrm{~A} \mathrm{~b}$ \\
\hline \multirow{6}{*}{$a^{*}$} & 0 & $-17.685 \pm 0.445 \mathrm{~A} \mathrm{bc}$ & $-16.930 \pm 0.070 \mathrm{Ac}$ & $-17.370 \pm 0.120 \mathrm{~A} \mathrm{~b}$ & $-16.835 \pm 0.005 \mathrm{~A} \mathrm{bc}$ \\
\hline & 2 & $-160.630 \pm 0.370 \mathrm{~A} \mathrm{bc}$ & $-17.430 \pm 0.140 \mathrm{~A} \mathrm{c}$ & $-16.560 \pm 0.070 \mathrm{~A} \mathrm{~b}$ & $-16.775 \pm 0.365 \mathrm{~A} \mathrm{bc}$ \\
\hline & 4 & $-16.290 \pm 0.120 \mathrm{~A} \mathrm{bc}$ & $-16.760 \pm 0.240 \mathrm{Abc}$ & $-16.175 \pm 0.275 \mathrm{~A} \mathrm{~b}$ & $-16.090 \pm 0.070 \mathrm{~A} \mathrm{~b}$ \\
\hline & 6 & $-17.120 \pm 0.330 \mathrm{~A} b c$ & $-16.550 \pm 0.140 \mathrm{~A} \mathrm{~b}$ & $-16.510 \pm 0.260 \mathrm{~A} \mathrm{~b}$ & $-16.940 \pm 0.350 \mathrm{~A} \mathrm{bc}$ \\
\hline & 8 & $-18.015 \pm 0.465 \mathrm{~A} \mathrm{c}$ & $-18.340 \pm 0.000 \mathrm{~A} \mathrm{~d}$ & $-18.590 \pm 0.170 \mathrm{~A} \mathrm{~b}$ & $-17.440 \pm 0.400 \mathrm{~A} \mathrm{c}$ \\
\hline & 10 & $-13.930 \pm 0.730 \mathrm{~A} \mathrm{a}$ & $-15.060 \pm 0.380 \mathrm{~A} \mathrm{a}$ & $-13.070 \pm 1.570 \mathrm{~A} \mathrm{a}$ & $-13.290 \pm 0.400 \mathrm{~A} \mathrm{a}$ \\
\hline \multirow{6}{*}{$b^{*}$} & 0 & $27.340 \pm 0.090 \mathrm{~A} \mathrm{ab}$ & $25.670 \pm \mathrm{B} \operatorname{cd} 0.520$ & $27.105 \pm 0.185 \mathrm{~A} \mathrm{~b}$ & $25.010 \pm 0.310 \mathrm{~B} a b$ \\
\hline & 2 & $24.725 \pm 0.865 \mathrm{ABcd}$ & $27.595 \pm 0.205 \mathrm{~A} \mathrm{ab}$ & $24.450 \pm 0.000 \mathrm{AB} \mathrm{c}$ & $25.215 \pm 1.175 \mathrm{AB} a b$ \\
\hline & 4 & $24.925 \pm 0.365 \mathrm{~A} \mathrm{bcd}$ & $26.590 \pm 0.580 \mathrm{~A} \mathrm{bc}$ & $24.640 \pm 0.980 \mathrm{~A} \mathrm{c}$ & $24.520 \pm 0.210 \mathrm{Ab}$ \\
\hline & 6 & $26.660 \pm 0.740 \mathrm{~A} \mathrm{abc}$ & $24.460 \pm 0.090 \mathrm{ABd}$ & $23.980 \pm 0.470 \mathrm{~B} \mathrm{c}$ & $25.350 \pm 0.660 \mathrm{AB} a b$ \\
\hline & 8 & $28.625 \pm 1.045 \mathrm{~A} \mathrm{a}$ & $29.240 \pm 0.110 \mathrm{~A} \mathrm{a}$ & $29.800 \pm 0.840 \mathrm{~A} \mathrm{a}$ & $27.055 \pm 0.465 \mathrm{~A} \mathrm{a}$ \\
\hline & 10 & $23.325 \pm 0.565 \mathrm{~A} \mathrm{~d}$ & $24.930 \pm 0.880 \mathrm{~A} \mathrm{~cd}$ & $23.235 \pm 1.005 \mathrm{~A} \mathrm{c}$ & $24.335 \pm 0.305 \mathrm{~A} \mathrm{~b}$ \\
\hline \multirow{6}{*}{$\begin{array}{c}\text { Chroma } \\
\left(\mathrm{C}^{*}\right)\end{array}$} & 0 & $32.580 \pm 0.310 \mathrm{~A} \mathrm{ab}$ & $30.755 \pm 0.465 \mathrm{~B} \mathrm{~cd}$ & $32.195 \pm 0.215 \mathrm{~A} \mathrm{ab}$ & $30.150 \pm 0.260 \mathrm{~B} a b$ \\
\hline & 2 & $29.805 \pm 0.925 \mathrm{ABbc}$ & $32.650 \pm 0.240 \mathrm{~A} \mathrm{~b}$ & $29.535 \pm 0.035 \mathrm{~B} \mathrm{bc}$ & $30.295 \pm 1.185 \mathrm{AB} a b$ \\
\hline & 4 & $29.785 \pm 0.375 \mathrm{~A} \mathrm{bc}$ & $31.435 \pm 0.615 \mathrm{~A} \mathrm{bc}$ & $29.485 \pm 0.965 \mathrm{~A} \mathrm{bc}$ & $29.340 \pm 0.220 \mathrm{~A} \mathrm{bc}$ \\
\hline & 6 & $31.695 \pm 0.795 \mathrm{~A} \mathrm{ab}$ & $29.560 \pm 0.150 \mathrm{ABd}$ & $29.120 \pm 0.530 \mathrm{~B} b c$ & $30.495 \pm 0.735 \mathrm{AB} a b$ \\
\hline & 8 & $33.845 \pm 1.115 \mathrm{~A} \mathrm{a}$ & $34.520 \pm 0.090 \mathrm{~A} \mathrm{a}$ & $35.140 \pm 0.810 \mathrm{~A} \mathrm{a}$ & $32.200 \pm 0.610 \mathrm{~A} \mathrm{a}$ \\
\hline & 10 & $27.185 \pm 0.865 \mathrm{~A} \mathrm{c}$ & $29.130 \pm 0.950 \mathrm{~A} \mathrm{~d}$ & $26.725 \pm 1.605 \mathrm{~A} \mathrm{c}$ & $27.850 \pm 0.000 \mathrm{~A} \mathrm{c}$ \\
\hline \multirow{6}{*}{$\begin{array}{l}\text { Hue angle } \\
\qquad\left(h^{o}\right)\end{array}$} & 0 & $123.120 \pm 0.430 \mathrm{~A} \mathrm{a}$ & $123.530 \pm 0.430 \mathrm{~A} \mathrm{~b}$ & $122.710 \pm 0.050 \mathrm{~A} \mathrm{a}$ & $123.995 \pm 0.325 \mathrm{~A} \mathrm{a}$ \\
\hline & 2 & $124.050 \pm 0.400 \mathrm{~A} \mathrm{a}$ & $122.390 \pm 0.040 \mathrm{~B} \mathrm{c}$ & $124.180 \pm 0.110 \mathrm{~A} \mathrm{a}$ & $123.795 \pm 0.605 \mathrm{AB}$ a \\
\hline & 4 & $123.285 \pm 0.115 \mathrm{~A} \mathrm{a}$ & $122.320 \pm 0.190 \mathrm{~A} \mathrm{c}$ & $123.450 \pm 0.620 \mathrm{~A} \mathrm{a}$ & $123.460 \pm 0.020 \mathrm{~A} \mathrm{a}$ \\
\hline & 6 & $122.835 \pm 0.275 \mathrm{C} \mathrm{a}$ & $124.475 \pm 0.095 \mathrm{ABa}$ & $124.630 \pm 0.070 \mathrm{~A} \mathrm{a}$ & $123.865 \pm 0.185 \mathrm{Ba}$ \\
\hline & 8 & $122.505 \pm 0.465 \mathrm{~A} \mathrm{ab}$ & $122.125 \pm 0.105 \mathrm{~A} \mathrm{c}$ & $122.145 \pm 0.385 \mathrm{Aab}$ & $123.035 \pm 0.045 \mathrm{~A} \mathrm{a}$ \\
\hline & 10 & $120.850 \pm 0.850 \mathrm{~A} \mathrm{~b}$ & $121.135 \pm 0.295 \mathrm{~A} \mathrm{~d}$ & $119.370 \pm 1.840 \mathrm{~A} \mathrm{~b}$ & $118.800 \pm 1.010 \mathrm{~A} \mathrm{a}$ \\
\hline \multirow{6}{*}{ TPC } & 0 & $55.663 \pm 0.000 \mathrm{~A} \mathrm{a}$ & $55.163 \pm 1.375 \mathrm{~A} \mathrm{a}$ & $55.788 \pm 1.125 \mathrm{~A} \mathrm{a}$ & $57.662 \pm 7.250 \mathrm{~A} \mathrm{a}$ \\
\hline & 2 & $60.100 \pm 0.563 \mathrm{~A} \mathrm{a}$ & $59.100 \pm 3.562 \mathrm{~A} \mathrm{a}$ & $62.787 \pm 8.125 \mathrm{~A} \mathrm{a}$ & $57.788 \pm 0.000 \mathrm{~A} \mathrm{a}$ \\
\hline & 4 & $65.163 \pm 0.250 \mathrm{~A} \mathrm{a}$ & $58.038 \pm 4.375 \mathrm{~A} \mathrm{a}$ & $61.600 \pm 13.062 \mathrm{~A} \mathrm{a}$ & $62.162 \pm 0.375 \mathrm{~A} \mathrm{a}$ \\
\hline & 6 & $65.350 \pm 9.812 \mathrm{~A} \mathrm{a}$ & $65.538 \pm 5.250 \mathrm{~A} \mathrm{a}$ & $65.788 \pm 3.625 \mathrm{~A} \mathrm{a}$ & $68.225 \pm 1.188 \mathrm{~A} \mathrm{a}$ \\
\hline & 8 & $68.975 \pm 1.937 \mathrm{~A} \mathrm{a}$ & $57.413 \pm 0.000 \mathrm{~B} \mathrm{a}$ & $63.225 \pm 4.812 \mathrm{AB}$ a & $64.288 \pm 0.000 \mathrm{AB}$ a \\
\hline & 10 & $67.788 \pm 2.250 \mathrm{~A} \mathrm{a}$ & $57.350 \pm 8.062 \mathrm{~A} \mathrm{a}$ & $62.287 \pm 3.000 \mathrm{~A} \mathrm{a}$ & $65.663 \pm 5.875 \mathrm{~A} \mathrm{a}$ \\
\hline \multirow{6}{*}{ TAC } & 0 & $15.892 \pm 0.000 \mathrm{~A} \mathrm{a}$ & $15.517 \pm 0.542 \mathrm{~A} \mathrm{a}$ & $14.433 \pm 0.792 \mathrm{~A} \mathrm{a}$ & $15.767 \pm 1.292 \mathrm{~A} \mathrm{a}$ \\
\hline & 2 & $16.142 \pm 0.083 \mathrm{~A} \mathrm{a}$ & $15.767 \pm 1.292 \mathrm{~A} \mathrm{a}$ & $15.350 \pm 0.000 \mathrm{~A} \mathrm{a}$ & $15.433 \pm 1.125 \mathrm{~A} \mathrm{a}$ \\
\hline & 4 & $16.558 \pm 0.083 \mathrm{~A} \mathrm{a}$ & $15.683 \pm 3.542 \mathrm{~A} \mathrm{a}$ & $18.142 \pm 2.667 \mathrm{~A} \mathrm{a}$ & $17.433 \pm 1.042 \mathrm{~A} \mathrm{a}$ \\
\hline & 6 & $20.850 \pm 5.958 \mathrm{~A} \mathrm{a}$ & $18.350 \pm 3.458 \mathrm{~A} \mathrm{a}$ & $21.350 \pm 2.042 \mathrm{~A} \mathrm{a}$ & $19.892 \pm 0.500 \mathrm{~A} \mathrm{a}$ \\
\hline & 8 & $20.183 \pm 0.000 \mathrm{~A} \mathrm{a}$ & $16.267 \pm 0.875 \mathrm{~A} \mathrm{a}$ & $18.058 \pm 2.833 \mathrm{~A} \mathrm{a}$ & $15.517 \pm 1.375 \mathrm{~A} \mathrm{a}$ \\
\hline & 10 & $18.142 \pm 0.917 \mathrm{~A} \mathrm{a}$ & $15.642 \pm 3.167 \mathrm{~A} \mathrm{a}$ & $17.975 \pm 1.083 \mathrm{~A} \mathrm{a}$ & $18.850 \pm 3.292 \mathrm{~A} \mathrm{a}$ \\
\hline
\end{tabular}

SEM: Standard error of mean

$\mathrm{A}, \mathrm{B}, \mathrm{C} \rightarrow$ : In the same row, different upper cases indicate statistically significant differences between the groups $(\mathrm{p}<0.05)$

a, b, c $\downarrow$ : In the same column, different lower cases indicate statistically significant differences between the storage time $(\mathrm{p}<0.05)$ 
The chroma $\left(\mathrm{C}^{*}\right)$ values decreased in all treatments until the $6^{\text {th }}$ day of storage, and then increased. At the end of the storage, the greatest chroma was observed in $\mathrm{Ca}$ treatments and the lowest value was observed in $\mathrm{Ca}+\mathrm{UV}-\mathrm{C}$ treatments with also the lowest initial chroma values. It can be stated based on present findings that $\mathrm{Ca}+\mathrm{UV}$ treatments kept maturity going because had the least change and therefore in long-term pepper fruit storage, these treatments may be more effective than the other treatments. There is a decrease in $\mathrm{h}$ angle values in all treatments after the $6^{\text {th }}$ day of storage (Table 1 and Fig. 1). At the end of the 10-day storage, the lowest $\mathrm{h}$ angle value was obtained from Ca treatments and the greatest value was obtained from UV-C treatments. The effects of present treatments on $\mathrm{a}^{*}$ values were not found to be significant $(p>0.05)$ throughout the storage period. Since $a^{*}$ values indicate the color change from green to red, control treatments were less effective than the other treatments. The effects of treatments on $b^{*}$ values were found to be significant only on $6^{\text {th }}$ day of storage ( $\mathrm{p}<0.05)$ (Table 1 and Fig. 1). Perez-Ambrocio et al. (2018) applied UV-C to Habanero chili pepper at various times and kept pepper fruits at $0{ }^{\circ} \mathrm{C}$ for 35 days. Contrary to present findings, researchers reported slightly increasing $\mathrm{L}^{*}$ and $\mathrm{a}^{*}$ values and decreasing $b^{*}$ values with UV-C treatments. Such differences were mainly resulted from differences in pepper types and harvest times.
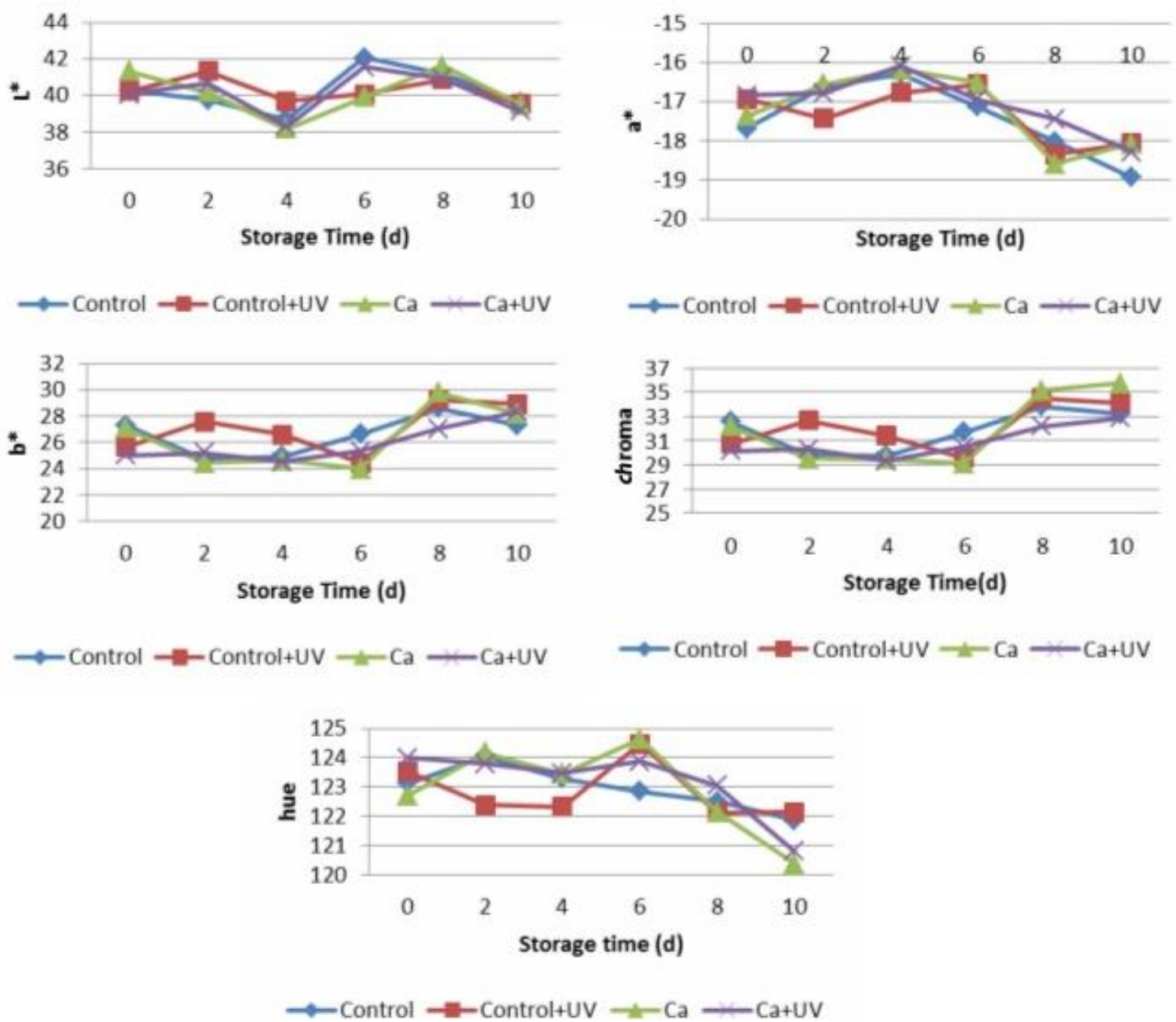

Figure 1. Color parameters of pepper treated with $\mathrm{Ca}$ and UV-C light at the beginning and end of 10-day storage 
The effects of treatments and storage periods on total phenolic content and total antioxidant capacity of pepper were also not found to be significant ( $p>0.05)$. In all treatments, a slight increase was observed in total phenolic content and total antioxidant capacity of the samples until the $6^{\text {th }}$ day of storage, but afterwards a decrease was observed as compared to the initial values (Table 1 and Fig. 2). Such an increase was an expected case as the physiological and pathological deterioration will increase with the prolongation of the cold storage period. Castro-Concha et al. (2014) investigated total phenolic content and antioxidant capacities of 'Habanero' (Capsicum chinense) peppers at different maturity levels and Perez-Ambrocio et al. (2018) applied UV-C to the same pepper cultivar for 0.5 and $3 \mathrm{~min}$ and both reported increased total phenolics and antioxidants. Such findings conflict with the present ones because of differences in pepper types and cultivation places. Researchers also indicated that 'Habanero' chili pepper had greater quantities of phenolics in research countries than in Mexico.
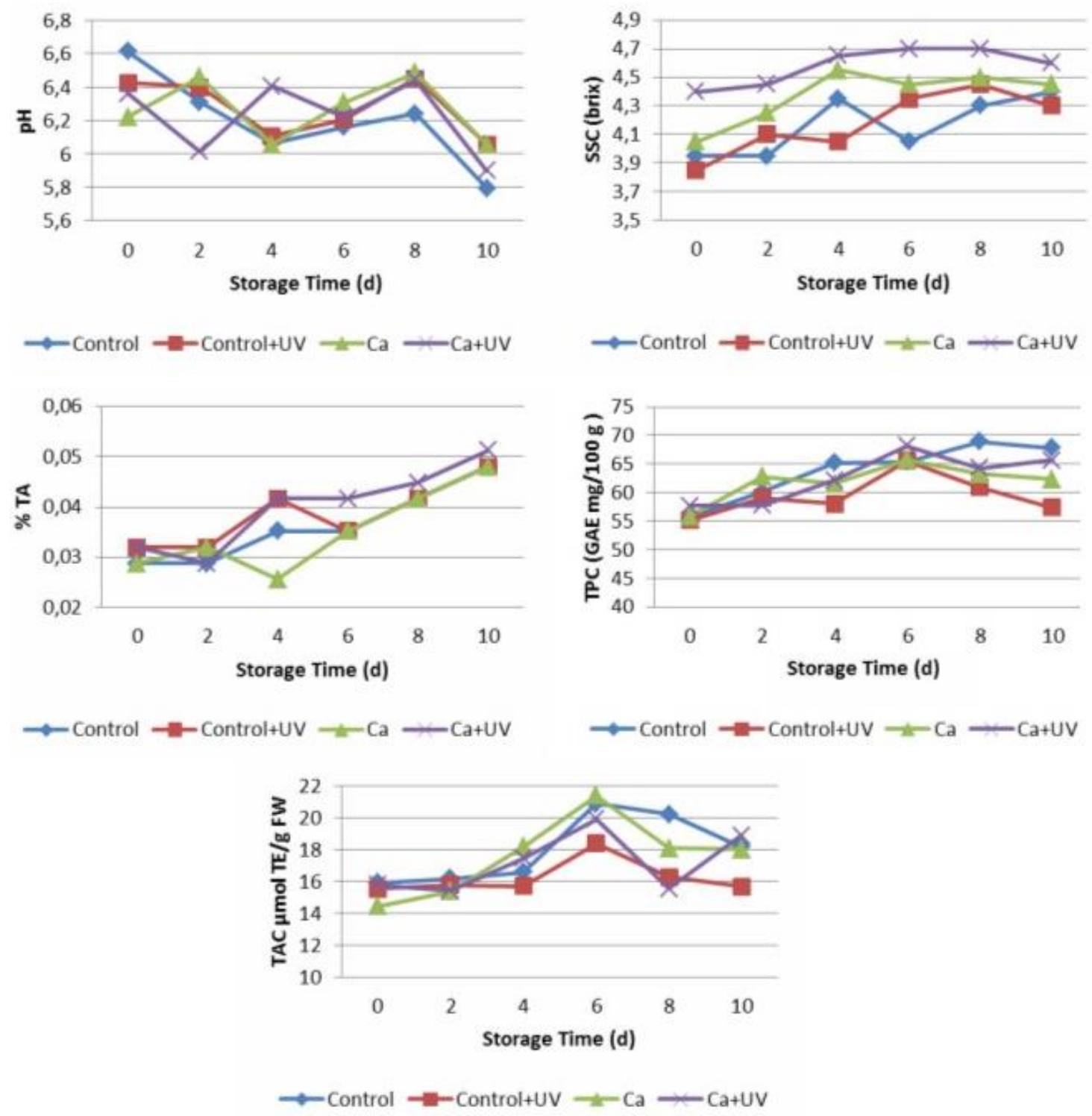

Figure 2. The $p H$, titratable acidity (TA), soluble solids content (SSC), total phenolic content (TPC) and total antioxidant capacity (TAC) of ' $\mathrm{c}$. Mertcan F1' pepper for 10-day storage 


\section{Conclusion}

In general, $\mathrm{Ca}+\mathrm{UV}-\mathrm{C}$ treatments were found to be the most successful treatments for preservation of quality attributes throughout the cold storage. As compared to the initial values, $\mathrm{Ca}+\mathrm{UV}-\mathrm{C}$ treatments yielded the lowest changes in quality attributes after 10 days of storage. The $\mathrm{Ca}+\mathrm{UV}-\mathrm{C}$ treatments also reduced color changes and increased total phenolic content and total antioxidant capacity of the plants. Present findings revealed that UV-C treatments slowed the increase in total phenolic content and total antioxidant capacity. Therefore, it can be stated that $\mathrm{Ca}+\mathrm{UV}-\mathrm{C}$ treatments were quite effective in storage of peppers for longer periods and better quality.

As a result, since the post-harvest UV-C treatments do not contain any chemicals and pre-harvest $\mathrm{Ca}$ treatments have no adverse effect on human health, they can reliably be used in pepper storage for longer periods without significant losses in quality attributes.

Acknowledgements. This research received no specific grant from any funding agencies in the public, commercial, or none-profit sectors.

\section{REFERENCES}

[1] Abbasi, N. A., Ashraf, S., Ali, I., Butt, S. J. (2015): Enhancing storage life of bell pepper by UV-C irradiation and edible coatings. - Pak. J. Agri. Sci. 52(2): 403-411.

[2] Alothman, M., Bhat, R., Karim, A. A. (2009): Effects of radiation processing on phytochemicals and antioxidants in plant produce. - Trends Food Sci. Tech. 20: 201-212.

[3] Andrade-Cuvi, M. J., Vicente, A. R., Concellón, A., Chaves, A. R. (2011): Changes in red pepper antioxidants as affected by UV-C treatments and storage at chilling temperatures. - LWT-Food Sci. Technol. 44: 1666-1671.

[4] Benzie, I. E. F., Strain, J. J. (1996): The ferric reducing ability of plasma (FRAP) as a measure of "antioxidant power": the FRAP assay. - Analytical Biochemistry 239: 70-76.

[5] Castro-Concha, L. A., Tuyub-Che, J., Moo-Mukul, A., Vazquez-Flota, F. A., MirandaHam, M. L. (2014): Antioxidant capacity and total phenolic content in fruit tissues from accessions of Capsicum chinense Jacq. (Habanero pepper) at different stages of ripening. - Sci. World J. 1-5.

[6] Chen, F., Liu, H., Yang, H., Lai, S., Cheng, X., Xin Y, Yang, B., Hou, H., Yao, Y., Zhang, S., Bu, G., Deng, Y. (2011): Quality attributes and cell wall properties of strawberries (Fragaria annanassa Duch.) under calcium chloride treatment. - Food Chem. 126: 450-459.

[7] Crosby, K. M. (2008): Pepper. In: Prohens, J., Nuez, F. (Eds.), Vegetables, II: Fabaceae, Liliaceae, Umbelliferae, and Solanaceae. - Springer, New York.

[8] Demirdoven, A., Batu, A., Ece, A. (2006): Biberin modifiye atmosferde paketlenerek depolanmasi. - Gida Teknolojileri Elektronik Dergisi 1: 1-7.

[9] Erdogmus, A. O., Kaynas, K., Kaya, S. (2015): Kirmızi biberde (Capsicum annuumL. cv. Kapya) bazi hasat sonrasi uygulamalarin depolama kalitesi uzerine etkileri. - COMÜ Zir. Fak. Derg. 3 (2): 45-53.

[10] FAOSTAT (2014): FAO Statistical Database. - $\quad$ http:// http://www.fao.org/faostat/en/\#data/QC. Accessed on 11 December 2015.

[11] Frank, C. A., Nelson, R. G., Simonne, E. H., Behe, B. K., Simonne, A. H. (2005): Consumer preferences for color, price and vitamin $\mathrm{C}$ content of bell peppers. HortScience 36: 795-800.

[12] Gunay, A. (2005): Sebze yetiştiriciliği, Cilt II. - Meta Basimevi, İzmir.

[13] Halloran, N., Yanmaz, R., Kasim, M. U., Kasim, R. (2000): Modified atmospheric storage of 'Kandil' bell pepper cultivar. - Gida. 25(2): 129-132. 
[14] Hardenburg, R. E., Watada, A. E., Wang, C. Y. (1986): The Commercial Storage of Fruits, Vegetables and Florist and Nursery Stocks. Agriculture Handbook 66. - U.S. Dept. Agric. Research Service, Washington.

[15] Hernandez-Munoz, P., Almenar, E., Ocio, M. J., Gavara, R. (2006): Effect of calcium dips and chitosan coatings on postharvest life of strawberries (Fragaria ananassa). Postharvest Biol. Technol. 39: 247-253.

[16] Koutchma, T., Popović, V., Ros-Polski, V., Popielarz, A. (2016): Effects of ultraviolet light and high-pressure processing on quality and health-related constituents of fresh juice products. - Compr. Rev. Food Sci. F. 15: 844-867.

[17] Lester, G. E., Grusak, M. A. (2000): Postharvest application of chelated and non-chelated calcium dip treatments to commercially grown honey dew melons: effects on peel attribute tissue calcium concentration, quality, and consumer preference following storage. - Hortic. Technol. 11: 561-566.

[18] Mercier, J., Baka, M., Reddy, B., Corcuff, R., Arul, J. (2001): Shortwave ultraviolet irradiation for control of decay caused by Botrytis cinerea in bell pepper: induced resistance and germicidal effects. - J. Am. Soc. Hort. Sci. 126: 128-133.

[19] Nyanjage, M., Nyalala, S. P. O., Illa, A. O, Mugo, B. W, Limbe, A. E, Vulimu, E. M. (2005): Extending post-harvest life of sweet pepper (Capsicum annum L.'California Wonder') with modified atmosphere packaging and storage temperature. - Agric. Trop. Subtrop. 38: 28-34.

[20] Pérez-Ambrocio, A., Guerrero-Beltrán, J. A., Aparicio-Fernández, X., Ávila-Sosa, R., Hernández-Carranza, P., Cid-Pérez, S., Ochoa-Velasco, C. E. (2018): Effect of blue and ultraviolet-C light irradiation on bioactive compounds and antioxidant capacity of habanero pepper (Capsicum chinense) during refrigeration storage. - Postharvest Biology and Tech. 135: 19-26.

[21] Rao, R. T. V., Gol, N. B., Shah, K. K. (2011): Effect of postharvest treatments and storage temperatures on quality and shelf life of sweet pepper (Capsicum annum L.). Scientia Hoticulturae 132: 18-26.

[22] Rodov, V., Ben-Yehoshua, S., Fierman, T., Fang, D. (1995): Modified-humidity packaging reduces decay of harvested 'Red Bell' pepper fruit. - HortScience 30(2): 299302.

[23] Salk, A., Arın, L., Deveci, M., Polat, S. (2008): Ozel sebzecilik. - Namik Kemal Universitesi Ziraat Fakultesi Basimevi, Tekirdag.

[24] Simonne, A. H., Simonne, E. H., Eitenmiller, R. R., Mills, H. A., Green, N. R. (1997): Ascorbic acid and provitamin A contents in unusually colored bell peppers (Capsicum annuum L.). - J. Food Comp. Anal. 10: 299-311.

[25] Snowdon, A. L. (1992): Color atlas of postharvest diseases and disorders of fruit and vegetables (Vol. 2). - Walfe Publishing, Aylesbury.

[26] Swain, T., Hillis, W. E. (1959): The phenolic constituents of Prunus domestica. I.- The quantitative analysis of phenolic constituents. - Journal of the Science of Food and Agriculture 10: 63-68.

[27] Vicente, A. R., Pineda, C., Lemoine, L., Civello, P. M., Martinez, G. A., Chaves, A. R. (2005): UV-C treatments reduce decay, retain quality and alleviate chilling injury in pepper. - Postharvest Biology and Tech. 35: 69-78.

[28] Vural, H., Esiyok, D., Duman, İ. (2000): Kultur sebzeleri (Sebze yetiştirme). - Ege Universitesi Basimevi, İzmir.

[29] Watkins, C. B. (2002): Ethylene Synthesis, Mode of Action Consequences and Control. In: Knee, M. (ed.) Fruit Quality and Its Biological Basis. Sheffield Academic Press, Sheffield. 